\title{
Motivation for accounting human resources by material stimulation: The case of accounting service firms in Hanoi, Vietnam
}

\author{
Duc Tai Do ${ }^{a^{*}}$, Son Tung Ha ${ }^{b}$, Manh Dung Tran ${ }^{b}$ and Thanh Trung Nguyen ${ }^{c}$
}

\author{
${ }^{b}$ National Economics University, Vietnam \\ cPhenikaa University, Vietnam
}

${ }^{a}$ University of Labor and Social Affairs, Vietnam

\section{A B S T R A C T}

\begin{abstract}
This study is conducted for evaluating the motivation for accounting human resources by material stimulation in the accounting service firms in Hanoi. Based on literature review and the results of some interviews, dependent variable of the motivation for accounting human resources by material stimulation includes seven attributes. The study has also performed some descriptive analysis, Cronbach's Alpha, Independent T-test and ANOVA for measuring the motivation for accounting human resources by material stimulation in the accounting service firms in Hanoi. The results show that the motivation for accounting human resources by material stimulation achieved an average of 3.74 and with Cronbach's Alpha coefficient greater than 0.6. The study does not find any difference on evaluation of the motivation for accounting human resources by material stimulation in terms of gender and job experience. Based on the findings, some recommendations are given for improving the motivation for accounting human resources by material stimulation in the accounting service firms in Hanoi.
\end{abstract}

\section{Introduction}

The incremental development of science and technology as well as the growing measure and diversity of their applications to production have further advanced societal production. However, the human resources in general and the accounting personnel in particular are still determinant factors in the production process, an indispensable source of power for any organization or enterprise and more importantly, for socio-economic growth. The quality of human resources in accounting field greatly influences corporate reputation and development (Nguyen, 2014). Human motivation is the application of a system of policies, measures, management methods affecting employees, making them motivated at work, more satisfied in their work and desire to contribute to the business (Nguyen, 2015). Human motivation is one of the important contents of human resource management, in order to motivate employees to work enthusiastically, stimulate the positivity, creativity of workers, and improve the ability labor productivity. Human motivation is one of the important solutions, being a leverage, breakthrough, promoting other factors towards the set goals. Human motivation brings many benefits for workers, businesses and society and depends on many different factors (Nguyen, 2015).

\footnotetext{
* Corresponding author. Tel.: +(84)9509101

E-mail address: taiketoanquocte@gmail.com (D. T. Do) 
The accounting service firms in Hanoi provide accounting services. These firms play an important role in assisting and advising investors and firms on the laws, regimes and financial and accounting institutions of State; guiding firms to make vouchers, bookkeeping, tax calculation and financial statements. However, the accounting service firms in Hanoi have faced many difficulties, such as increasingly fierce competition and the quality of human resources did not meet the requirements. In the accounting service firms, human reource accounting is mainly responsible for all activities of the companies. The development of the company, accounting human reource plays the most important role, creating value for the goals set by the company.

The accounting services firms have activities to motivate human, create a friendly and co-operative working environment to promote the initiative of employees. However, motivation for accounting human resources still has certain limitations such as lack of having desired results, lack of real motivation for accounting human resources. There are qualified individuals who have not promoted their strengths, and have not tried to find success in their works, so they often tend to be bored and be frustrated and have not devoted all their abilities. Finding measures to improve motivation for accounting human resources plays an important role to help them be more enthusiastic and creative.

\section{Literature Review}

In the world, there are many researches on human motivation, such as Maslow (1943) and Adams (1961), showing that: Human motivation must include measures to satisfy the demand of workers on the basis of ensuring fairness. When grasping the roots that lead to the different motivations of each person, human resources (HR) professionals will devise various strategies for their organizations. According to Vroom (1964), work motivation depends on the individuals' expectations about their abilities to perform their tasks and on receiving the desired rewards. Moreover, employees' work motivation become strong when they believe that a certain endeavor will bring some achievement, which lead to some rewards as they wish. Shiraz and Rashid (2011) point out the relationship and difference in motivation to work with satisfaction, specifically, the difference between advancement opportunities and leadership styles in human motivation.

In Vietnam, Ho (2014) studied the status of motivational human at Vinaincon Company including: (i) Motivating by material stimulation and (ii) motivating through spiritual encouragement. According to Nguyen (2015), in order to motivate human, firms can use methods such as financial stimulation including measures related to salary, bonus, allowances, other benefits and services; spiritual stimulation includes measures to create stable jobs for employees, training to improve workers' qualifications, building a healthy and positive atmosphere in firms, and organizing emulation movements. Bui (2018) presented 3 groups of solutions to complete the status of motivational human in small and medium firms, including: (i) Completing the work of salary, bonus, allowance and social welfare (ii) improving working environment and conditions and (iii) training activities should be conducted regularly and continuously to ensure quality. In the field of accounting, there are no adequate studies on the motivation for accounting human resources by material stimulation in Vietnam. There are some studies on different factors influencing on the performance of accounting system (Do \& Nguyen; 2016; Do et al., 2018; Truong et al., 2018). This study evaluates the motivation for accounting human resources by material stimulation in accounting service firms in Hanoi. In addition, we employ both research methodologies of qualitative and quantitative to evaluate the motivation for accounting human.

\section{Research Methodology}

We used a qualitative research methodology based on some in-depth interviews with 5 lecturers with extensive experiences in accounting in accounting service firms of the National Economics University, University of Labor and Social Affairs and Trade Unions University in Vietnam. At the same time, we interviewed 5 experts working as director, chief accountants and general accountants in accounting service firms. The results of the interviews include motivation for accounting human resources by material stimulation. Based on the prior studies and results of qualitative research through expert 
interviews, we have conducted inductive method to verify, adjust and add attributes in questionnaires for collecting final data of the research. Inheriting the results conducted by Brooks (2007), Rashid (2011), Ho (2014), Nguyen (2015) and using qualitative research methodology through interviews with experts, we identify motivation for accounting human resources by material stimulation (MS) including seven attributes as follows,

$\mathrm{MS}_{1}$ : Monthly salary is commensurate with the responsibility and quality of work.

MS2: Salaries are paid on time.

MS3: Compared to the common ground, the salary at the firms reached a high level.

MS4: The firm always commends timely for accounting human resources with outstanding achievements.

MS5: The results of commendation review reflect the contribution level of accounting human resources.

MS6: The allowance for accounting human resources is quite reasonable.

MS7: The firm's welfare regime and services are quite good.

Then, we have designed a questionnaire consisting of 7 variables with a 5-point Likert scale from 1 "not totally agree" to 5 "fully agree". The method of data collection was accomplished through the survey and subjects were accountants doing in accounting service firms in Hanoi. We sent 200 questionnaires and received the feedback of 175. After checking the information on the votes, there were 145 questionnaires with full information for data entry and analysis, the size of this sample was consistent with study of Gorsuch (1983). We used both qualitative and quantitative approaches for analysis data. SPSS is a tool to support us to have descriptive statistics, Cronbach's Alpha, Independent T-test and ANOVA were used for evaluating and measuring the motivation for accounting human resources by material stimulation in the Accounting service firms in Hanoi.

\section{Results and Discussion}

\subsection{Descriptive Statistics}

Fig. 1 shows personal characteristics of the participants in our survey.

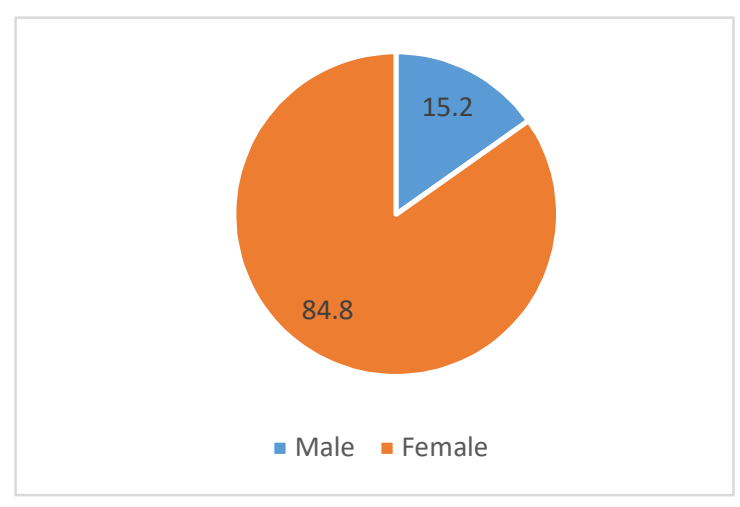

Gender

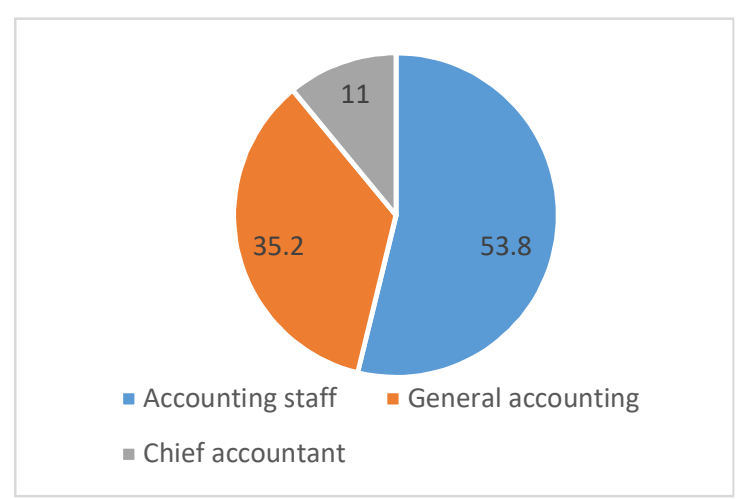

Job description

Fig. 1. Personal characteristics of the participants

Fig. 1 shows that among the 145 respondents, $15.2 \%$ of the participants were male while the remaining 123 were female, representing for $84.8 \%$. Of these, 16 of them worked as chief accountants, accounting for $11.0 \%$; 51(35.4\%) worked as General accounting and $53.8 \%$ of the participants were working as general accountants. Data in Table 1 illustrate that the respondents agree with the dependent variables of "the motivation for accounting human resources by material stimulation" where seven attributes were quite high with an average of 3.74 compared with the highest of the Likert 5-point scale. All 7 attributes were rated at an average of 2.75 or higher. 
Table 1

Descriptive Analysis of Attributes of the motivation for accounting human resources by material stimulation

\begin{tabular}{ccccccc}
\hline & $\mathrm{N}$ & Minimum & Maximum & Mean & Std. Deviation \\
\cline { 2 - 7 } & Statistic & Statistic & Statistic & Statistic & Statistic \\
\hline MS1 & 145 & 1 & 5 & 3.89 & 1.119 \\
MS2 & 145 & 2 & 5 & 4.08 & .651 \\
MS3 & 145 & 1 & 5 & 3.74 & .943 \\
MS4 & 145 & 1 & 5 & 2.75 & 1.031 & .656 \\
MS5 & 145 & 2 & 5 & 3.99 & .955 \\
MS6 & 145 & 1 & 5 & 3.86 & .912 \\
\hline MS7 & 145 & 1 & 5 & 3.88 & \\
\hline
\end{tabular}

\subsection{Testing Cronbach's Alpha}

The motivation for accounting human resources by material stimulation has been measured by the Cronbach's Alpha with coefficient of 0.645. Results of testing Cronbach's alpha of attributes are presented in Table 2 as follows,

Table 2

Results of Cronbach's Alpha Testing of Attributes

\begin{tabular}{cccccc}
\hline & $\begin{array}{c}\text { Scale Mean } \\
\text { if Item } \\
\text { Deleted }\end{array}$ & $\begin{array}{c}\text { Scale } \\
\text { Variance if } \\
\text { Item Deleted }\end{array}$ & $\begin{array}{c}\text { Corrected } \\
\text { Item-Total } \\
\text { Correlation }\end{array}$ & $\begin{array}{c}\text { Cronbach's Alpha if } \\
\text { Item Deleted }\end{array}$ \\
\hline MS1 & 22.30 & 7.141 & .376 & .635 \\
\\
MS2 & 22.10 & 7.024 & .406 & .628 & .644 \\
MS3 & 22.45 & 7.138 & .386 & .609 \\
MS4 & 23.43 & 8.872 & .302 & .629 \\
MS5 & 22.20 & 7.050 & .392 & .607 \\
MS6 & 22.32 & 6.568 & .480 & .389 & .625 \\
\hline
\end{tabular}

The results also show that attributes of the dependent variables had a Cronbach's Alpha coefficient greater than 0.6 and were less than the common Cronbach's Alpha coefficient; the correlation coefficient of all attributes was greater than 0.3 , so all the attributes of the dependent variables were statistically significant (Hoang \& Chu, 2008).

\subsection{Independent T-Test}

Comparing the results of the evaluation of the motivation for accounting human resources by material stimulation between men and women is shown in Table 3.

Table 3

Differences of the motivation for accounting human resources by material stimulation between Men and Women - Independent Test

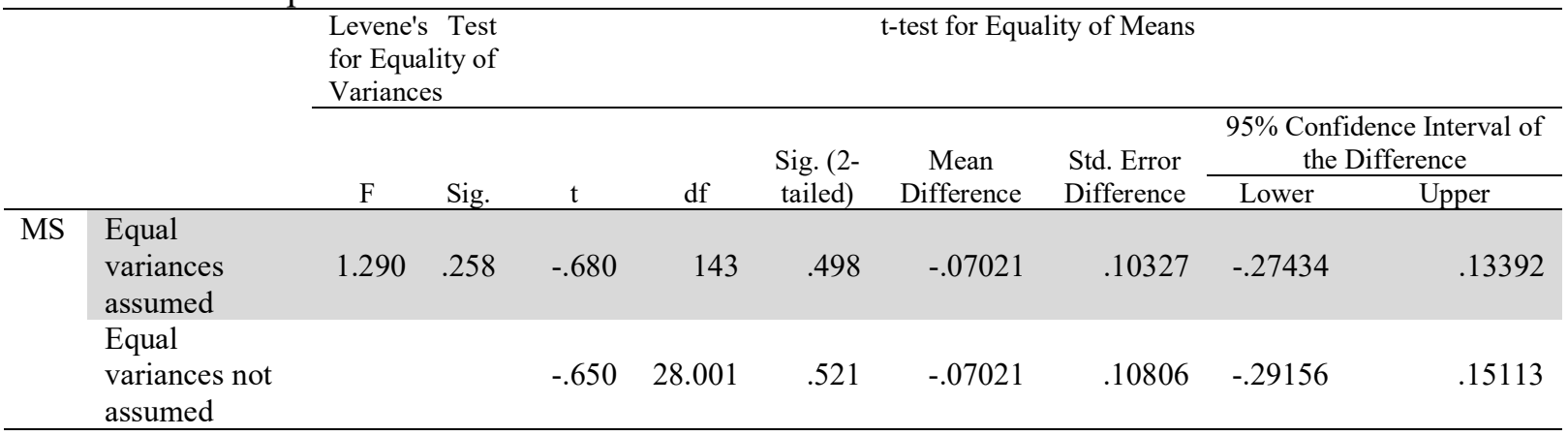


According to the results of Table 3, Sig Levene's Test $=0.258$ more than 0.05 ; the variance between the two female and male is not different. Moreover, Sig value T-Test $=0.498>0.05$, which means there is statistically no significant difference in the level of the motivation for accounting human resources by material stimulation competence evaluation by workers who have different genders (Hoang \& Chu, 2008).

\subsection{ANOVA analysis}

ANOVA test helps us perform a comparison for the results of the evaluation of the motivation for accounting human resources by material stimulation between the three subjects, including under 1-year job experience, from 1 to 3 years of job experience and over 3 years of job experience.

\section{Table 4}

Test of Homogeneity of Variances

\begin{tabular}{cccc}
\hline Levene Statistic & df1 & df2 & Sig. \\
\hline .946 & 2 & 142 & .391 \\
\hline
\end{tabular}

Table 4 shows that Sig Levene Statistic of 0.391 is more than 0.05 ; the hypothesis of homogeneity variance among the variable value groups (different experience with works) has not been violated.

\section{Table 5}

ANOVA

\begin{tabular}{lccccc}
\hline & Sum of Squares & df & Mean Square & F & Sig. \\
\hline Between Groups & .083 & 2 & .041 & .206 & .814 \\
Within Groups & 28.469 & 142 & .200 & & \\
\hline Total & 28.552 & 144 & & & \\
\hline
\end{tabular}

Table 5 shows that, Sig. $=0.814$ is more than 0.05 ; There is not statistically significant difference in the level of the motivation for accounting human resources by material stimulation for the accountant for the mentioned three groups of job experience (Hoang \& Chu, 2008).

\subsection{Discussion}

Income of accounting human resources

Normally, working time of human resources is calculated monthly, working 8 hours / day, 5.5 days / week. However, accountants need to work overtime during the accounting seasons. In our survey, $6.2 \%$ of the accountants earned only 4.5 Million VND and 4.1\% of them earned between 4.5 and 6.75 million VND. Moreover, $67.6 \%$ of the participants in our survey earned between 6.75 and 10 million VND and the rest of them earned more than 10 million VND. Fig. 2 shows the results of our survey.

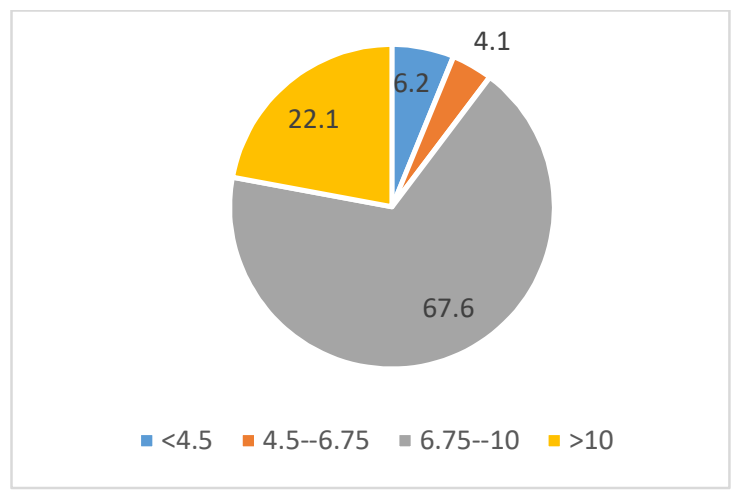

Fig. 2. The average salary of the participants in this survey

Income from wages represents a difference between job positions and work job experience. In addition 
to salary over time, accountants receive a sales salary for completed service provision contracts. If an accountant introduces new customers to the company, the accountant will also receive a commission of $5 \%$ to $10 \%$ of the revenue from that customer. Accounting service firms implement salary regime in January every year, based on evaluating the completion of work: Completing the assigned work schedule, Ensuring work efficiency and quality of work assigned, and complying with the rules and discipline of the firm, having creative contributions, opinions and suggestions that are effectively applied in the work. At accounting service firms, the payment of salaries to employees is paid by the accounting department. Wages of employees are calculated based on evaluating the performance of employees. Payment time: Firms pay monthly salaries for all employees on the days from the 3rd to 6 th of the following month. The way to receive salary is by bank transfer via ATM card system of the bank. Ensuring a timely payment of salary helps employees feel secure to have financial resources for their own lives. It also shows that accounting services companies are doing quite well on timely payment of employees' salaries and creating comfortable psychology for workers. In addition to ensuring a pay period, it is very important to pay the salaries for the responsibilities and quality of each employee in the organization, when conducting a survey on "Monthly salary is commensurate with the responsibility and quality of work"; The authors obtained the following chart of summary opinions of the accounting human resources as followed:

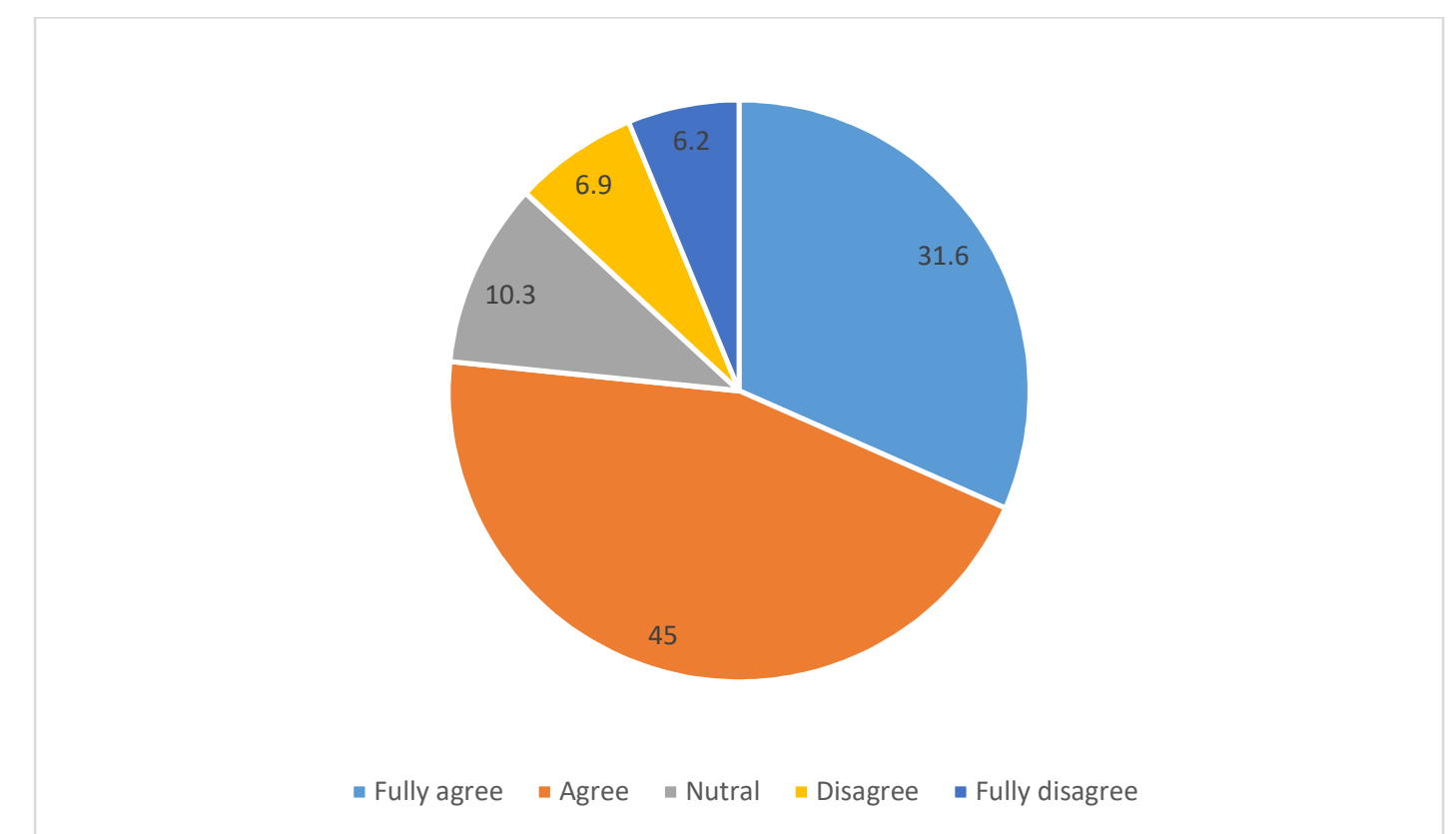

Fig. 3. The percentage of accounting human resources for "Monthly salary is commensurate with the responsibility and quality of work"

Fig. 3 shows that $31.6 \%$ of accounting human resources fully agree and $45 \%$ agree with the salaries given to accounting employees for accomplishing the responsibilities in their organizations by accounting service firms. Only $13.1 \%$ did not agree and totally disagree about wages and benefit packages. Accounting service firms have policies to increase salaries for HR accountants. Normally, once a year, the board of directors held a meeting on salary increase for accounting human resources, based on working time at the firm; dedication and creativity of accounting human resources; results of completing the work of accounting accountants and finally according to profitability of the organizations. 
Accountants have received bonuses (holidays, Tet holidays, company founding days), etc. The average level that accounting service firms pay bonuses to accountants is shown in Fig. 4 as follows,

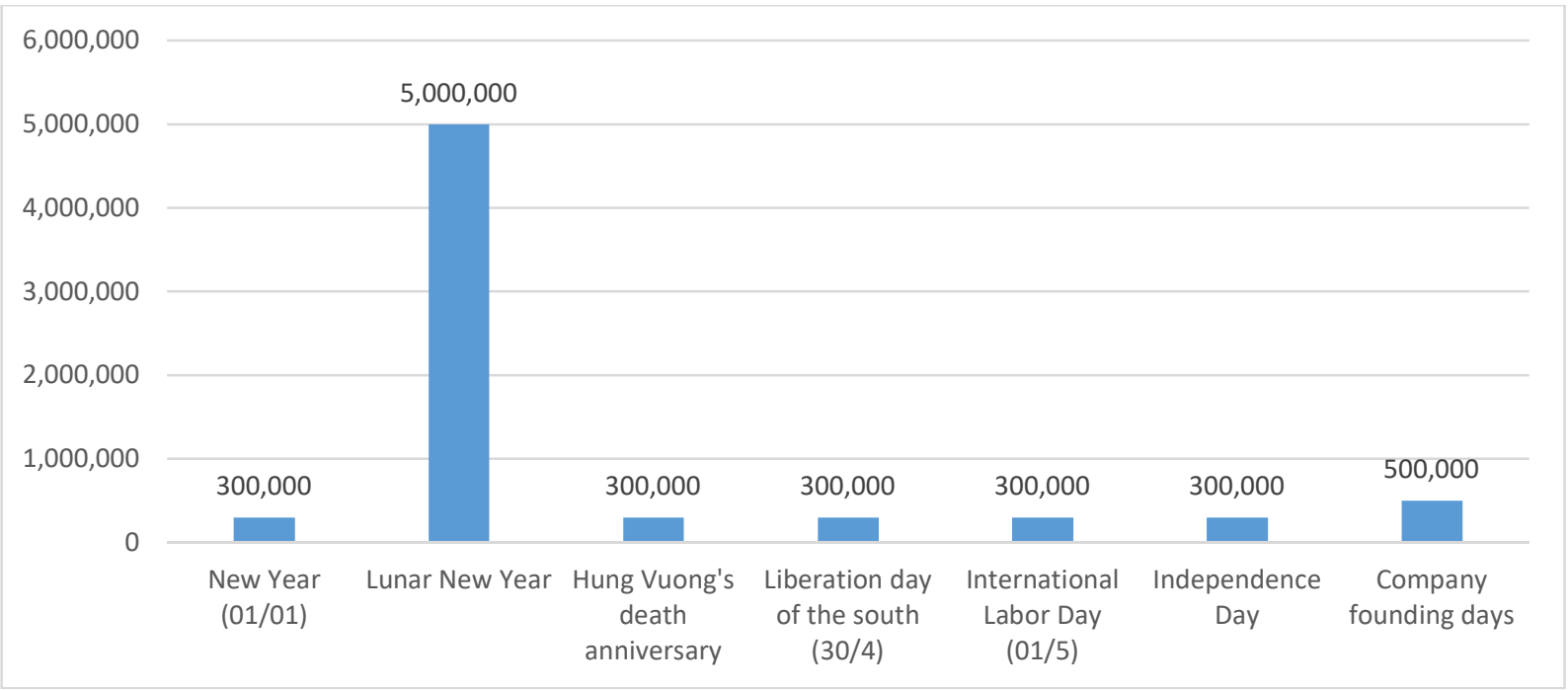

Fig. 4. Bonus payment regulations (Unit: VND)

In addition, every three months, the firm's board of directors and managers hold meetings and make an assessment on the performance of different individuals and departments in the company to carry out commendation. The form of bonuses at firms that are being mainly applied is cash bonus. Firms reward for the collective department fulfilled the task before the assigned deadline is 1,000,000/1 department / 1 time and reward for employees when they have positive new contributions, bringing great value to the firm is 1,000,000 / 1 initiative applied in practice / 1 time.

\section{Welfare regime}

Accountants have received welfare: traveling in the beginning of the spring, vacation every year, travel every year, etc. The time and place of traveling is at the beginning of the spring. In addition, the board of directors decides on travel and vacation schedules. Accounting service firms fully implement the social insurance regime for employees so that workers find that they are guaranteed when they fall ill; with female workers in the public, they are entitled for full support for maternity regimes. Accountants are entitled to leave from work, enjoy full salary for holidays and Tet. The accountants are able to leave for the absence of their own jobs and still get full pay when they get married, their children get married or their parents die. The average level that accounting service firms perform welfare payments for accounting HR is shown in Table 7 as follows.

\section{Table 7}

Regulation of welfare spending

\begin{tabular}{clc}
\hline No & Explanation & Payment \\
\hline 1 & International Women's Day (8/3) - Female labor & 300,000 \\
2 & Vietnamese Women's Day (October 20) - Female labor & 300,000 \\
3 & International Children's Day (June 1) & 300,000 \\
4 & The sick worker & 500,000 \\
5 & Parents are sick & 500,000 \\
6 & Children are sick & 500,000 \\
7 & Wedding workers & $1,000,000$ \\
8 & Four samples of women lost & 500,000 \\
9 & Vacation every year, travel every year (1 time / year) & $3,000,000$ \\
10 & Traveling in the beginning of the spring (1 time / year) & 500,000 \\
\hline
\end{tabular}




\section{Allowances:}

Accounting service firms in Hanoi have made allowances including: (i) Responsibility allowance, lunch allowance, gasoline allowance, phone allowance. Accounting HR receive these allowances at the same time of receiving monthly salaries. Accounting HR are entitled to an allowance at the rate of actual working days in the month. The average level that accounting service firms make allowances for accounting HR is shown in Fig. 5.

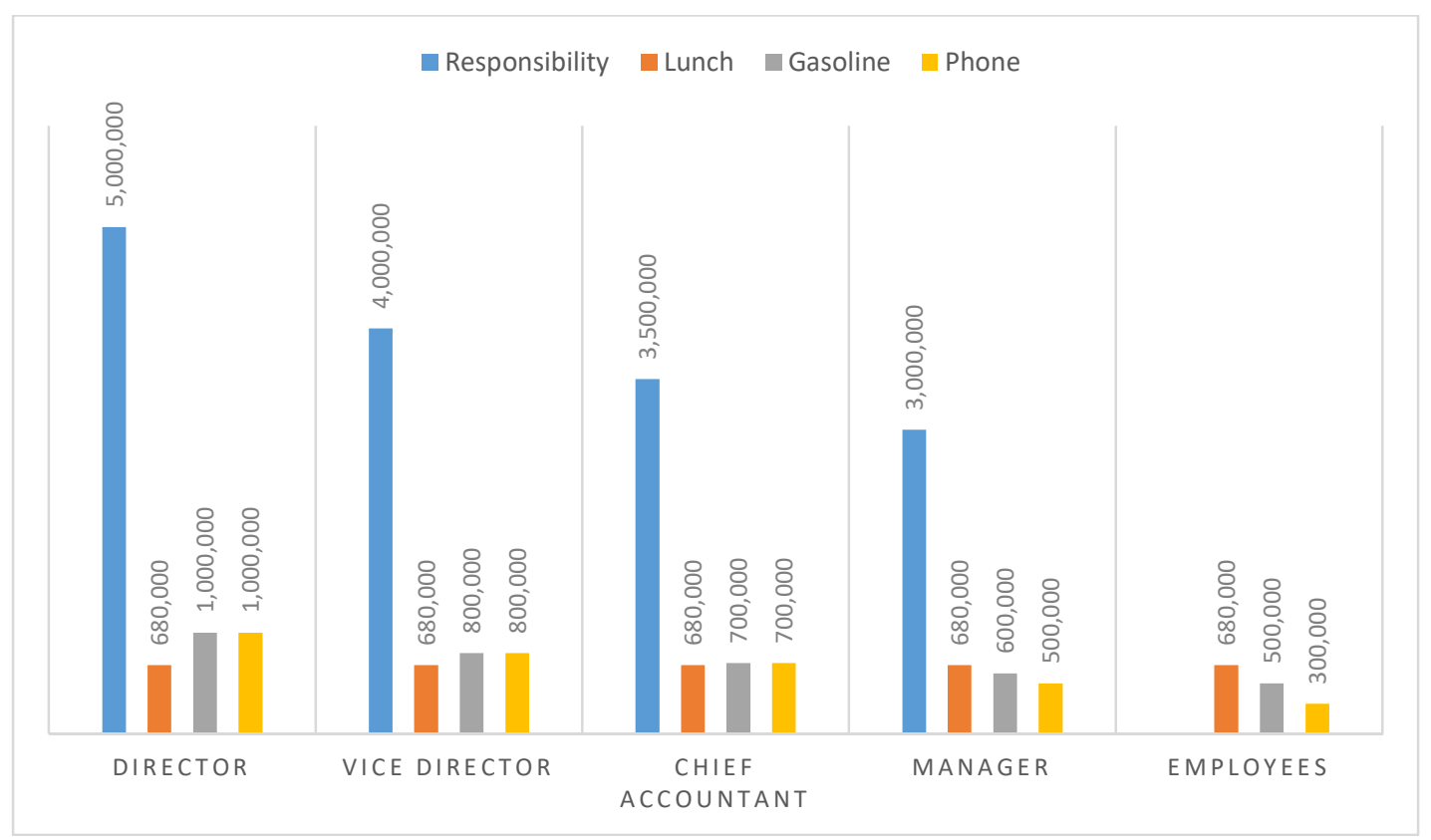

Fig. 5. Regulation of allowances (Unit: VND)

In addition to fixed allowances, accounting service firms also make payment for accounting human resources in terms of working expense. Support level includes eating and drinking, personal activities: If going back home in a day, the company supports 200,000 VND / day, if going from two days or more in neighboring provinces the firm gives 250,000 / day. The cost of train tickets, car tickets, motels, hotels, and accountants will be covered by vouchers of payment. When the income level that the accounting human resources receives is commensurate with the merit and work that makes them comfortable and effective, it will attract the dedication and wisdom of the people. Therefore, enterprises' managers of accounting services firms need to pay more attention, contributing to the use of effective accounting human resources, as a competitive factor in the process of sustainable development. Accounting human resources are educated and trained quite well in universities, colleges and accounting service firms. However, an accounting department of human resources has not received the expected level, so there is still a phenomenon of accounting human resources for job jumps.

\section{Recommendations}

\section{Complete salary work associated with performance accountant}

The level of salaries for accountants must ensure satisfactory living, further learning, thus attract highquality accountants to work for Accounting Services Firms. In most cases, salary is the most effective driving force that has been applied so far. Types of labor remuneration play a key role in motivating workers to work for and create value for the firm. Therefore, it is necessary:

(i). to develop an effective performance assessment system to create the firm basis for the remuneration according to the level of work completion and the work performed; thus to maintain the current 
accounting human resources, as well as to attract and retain expert accountants, especially job placement. A high salary and recognition by the superiors can make accountants stick with Accounting Services Firms for a long period of time.

(ii). The forms of payment and paying salaries need to be conducted in a detailed, specific, fair, and accurate way: The department in charge of payroll management is responsible for explaining the ideas of the accounting HR on their salaries when they have questions.

(iii). Developing clear regulations on standards and conditions for wage increase, ensuring publicity and transparency. The division in charge of salary management needs to develop documents regulating specific standards. The conditions for salary increase and approval are approved by the Board of Directors of the company, with documents coming from the department, ensuring widespread dissemination to all employees and serious, public and transparent implementation.

(iv). Developing specific criteria for each employee to pay salary for the right people in the right job, needing to add criteria for seniority working for employees who have been with the company for many years.

(v). There is also a need to develop a job description suitable to the capacity and ability of accounting HR to meet the requirements of that job, thereby rationalizing the assignment and layout, choosing right person for the right job so that the accountant knows the specific job they have to do, accomplish it well and motivate themselves to work.

(vi). Enhancing fostering and improving the professional level of the Ministry of salary operations.

\section{Construction appropriate reward and welfare regimes}

Have a reward system that is written in documents for each reward level, celebrate a recognition ceremony to show support and consensus among employees, thus encourage creativity. The reward decision should be made in a timely manner: The employee has a reward to be rewarded as soon as possible. If it is not possible to award immediately, there must be praise right away for the outstanding achievements gained by the employee. Implementation of seniority bonus regime: For the accountants who make accounting for long-term companies, at the end of the year, they can be rewarded according to a certain level to encourage them to stick with the company.

\section{Diversify types of benefits:}

Currently, accounting services firms only apply compulsory forms of benefits but firms need to diversify types of benefits such as:

Organizing periodic health examination for employees, supporting bank loans for workers to stabilize their lives.

Establishing a trade union organization: an organization representing workers to establish a healthy, stable and attracting environment to labors.

Organizing counseling sessions on labor law so that employees can understand, trust and well implement the policies offered by the Company.

Implementing the reward regime for children of public employees who have achieved outstanding achievements in studying.

The content of service welfare programs should be contributed by accountants to create excitement for the programs. Because of the benefits for accounting human resources, it is necessary to survey the opinion of the accountant.

\section{Conclusion}

Nowadays, motivation for accounting human resources is one of the necessary measures for accounting service firms because of accounting human resources are people who directly contribute to the development of firms. Accounting service firms to attach special important to motivate for accounting 
human resources will urge accounting human resources engrossed work, strive to improve their skills to improve performance's accountant, contribute to improving business performance of the firm and raise income of the accountants. Human motivation's Accounting service firms are conformtable, satisfying the needs of accountants, accountants are assured of working and accountants have a strodependency to accounting service firms.

This study was conducted for evaluating the motivation for accounting human resources by material stimulation in the accounting service firms in Hanoi via payroll, evaluating the work performance, bonus measures, welfare, etc. Some recommendations were also given for improving the motivation for accounting human resources by material stimulation in the accounting service firms in Hanoi.

\section{References}

Adams, J.C. (1961). Wage inequities in a clerical task. Unpublished study. General Electric Company, New York.

Bui, T.X. (2018). Some solutions to perfect human motivation in small and medium enterprises. Journal of the Asia Pacific Economy, 4, 35-37.

Do, D. T., \& Nguyen, T.H. (2016). The impact of Vietnam accounting standard and tax law on completing work result of firm accountants in Vietnam. Proceedings of Accounting Integration. National Economics University, Part 1, 319-231.

Do, D.T., Truong, D.D., Tran, M.D. \& Nguyen, T.N.L. (2018). Determinants influencing performance of accountants: The case of Vietnam. International Journal of Economics and Finance, 10(7), 1-9.

Gorsuch, R. L. (1983). Factor Analysis. $2^{\text {nd }}$ ed., Hillsdale, NJ: Erlbaum.

Hoang, T., \& Chu, N.M.N (2008). Analysis of research data with SPSS. Hong Duc Publishing House.

Ho, D. V. (2014). Some solutions to perfect human motivation in VINAINCON. Industry and trade journal, 8-9, 88-89.

Maslow, A. (1943). A theory of human motivation. Psychological Review, 50(4), Jul 1943, 370-396.

Nguyen, T. H. N. (2014). The cooperation strengthening between universities and firms in order to increase the quality of accounting human resources training in the direction of integration. Science and Technology Journal, 23, 3-7.

Nguyen, T. M. A. (2015). Human motivation in the business transformation process of Vietnam post office. Asian economy in the Pacific journal, 8, 31-33.

Shiraz, N., Rashid, M., \& Riaz, A. (2011). The impact of reward and recognition programs on employee's motivation and satisfaction. Interdisciplinary Journal of Contemporary Research in Business, 3(3), 1428-1434.

Tran, M.D. \& Do, D.T. (2019). Quality of personnel via accountants' physical and mental strengths in multinational firms in Vietnam. The 15th Conference of International Federation of East Asian Management Associations, Innovation Management for the Sustainable and Inclusive Development in a Transforming Asia, Kyoto, Japan, 2019.

Truong, D.D., Do, D.T., \&Tran, M.D. (2018), Evaluation of Accountants' Performance: The Case of Vietnam. Research Journal of Finance and Accounting, 9(12), 39-46.

Vroom, V.H. (1964). Work and motivation. New York: Wiley.

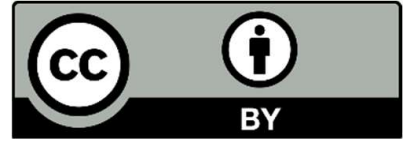

(C) 2020 by the authors; licensee Growing Science, Canada. This is an open access article distributed under the terms and conditions of the Creative Commons Attribution (CC-BY) license (http://creativecommons.org/licenses/by/4.0/). 